\title{
AN ANALYSIS OF SPEECH ACT ON BU TEJO'S UTTERANCES AS THE MAIN CHARACTERS IN TILIK MOVIE
}

\author{
Fadhilah$^{1}$, Didin Nuruddin Hidayat ${ }^{2}$, Alek $^{3}$ \\ 1,2,3.UIN Syarif Hidayatullah Jakarta, Indonesia.
}

Email: dilahlsmart@gmail.com ${ }^{1}, \underline{\text { didin.nuruddin @uinjkt.ac.id }}^{2}, \underline{\text { alek } @ u i n j k t . a c . i d}^{3}$.

\begin{abstract}
A movie is one of the famous media that is interesting in conveying messages to the people. Tilik movie is a short movie produced by Ravacana Films collaborating with the Culture Department of Special Region of Yogyakarta (DIY). This is viral in 2020 because it shows the culture and relates to the condition and real life of people in our society. Speech act is action carried out through language. Through speech act, people can make command, request, etc. The aim of this research to analyze the speech act used by Bu Tejo as one of the main characters in the Tilik movie. The primary sources of data were Bu Tejo's utterances in Tilik movie. This research also used its movie script as a secondary source. In speech act, there are three types of speech acts; a) locutionary acts, b) illocutionary acts, and c) perlocutionary acts. In this research, the researcher concerns to the illocutionary acts used by Bu Tejo as the main character in the Tilik. The researchers employed the descriptive qualitative method to analyze and describe the script. The script of the Tilik movie as the data of speech acts were taken and classified according to the John R. Searle's Concept of types of illocutionary acts and supported by Austin's concept. There are two research questions, 1) what kind of illocutionary acts and 2) how many frequency distributions are used by Bu Tejo as the main character in Tilik Movie. This research results in 70 illocutionary acts found in Bu Tejo's utterances, consisting of 41 representatives, 18 directives, and 11 expressives.
\end{abstract}

Keywords: Discourse Analysis, Illocutionary act, Speech act, Tilik movie

\begin{abstract}
ABSTRAK
Film merupakan salah satu media terkenal yang menarik untuk menyampaikan pesan kepada masyarakat. Film Tilik merupakan film pendek yang diproduksi oleh Film Rahwana bekerjasama dengan Dinas Kebudayaan Daerah Istimewa Yogyakarta (DIY). Ini viral di tahun 2020 karena menunjukkan budaya dan berkaitan dengan kondisi dan kehidupan nyata masyarakat kita. Tindak tutur adalah tindakan yang dilakukan melalui bahasa. Melalui tindak tutur, orang bisa membuat perintah, permintaan, dll. Tujuan dari penelitian ini adalah menganalisis tindak tutur yang digunakan oleh Bu Tejo sebagai salah satu pemeran utama dalam film Tilik. Sumber data primer adalah ucapan $\mathrm{Bu}$ Tejo dalam film Tilik. Penelitian ini juga menggunakan naskah filmnya sebagai sumber sekunder. Dalam tindak tutur, ada tiga jenis tindak tutur; a) tindakan lokusi, b) tindakan ilokusi, dan c) tindakan perlokusi. Dalam penelitian ini, peneliti membahas tentang ilokusi yang digunakan oleh $\mathrm{Bu}$ Tejo sebagai tokoh utama dalam Tilik. Peneliti menggunakan metode deskriptif kualitatif untuk menganalisis dan mendeskripsikan naskah. Naskah film Tilik sebagai data tindak tutur diambil dan diklasifikasikan menurut Konsep Jenis-jenis tindak ilokusi oleh John R. Searle dan didukung oleh konsep Austin. Ada dua pertanyaan penelitian, 1) ilokusi jenis apa dan 2) berapa distribusi frekuensi yang digunakan $\mathrm{Bu}$ Tejo sebagai pemeran utama dalam Film Tilik. Penelitian ini menghasilkan 70 tindak ilokusi yang ditemukan dalam tuturan Bu Tejo, terdiri dari 41 perwakilan, 18 arahan, dan 11 ekspresif.
\end{abstract}

Kata Kunci: Analisis Wacana, Tindak Ilokusi, Tindak Pidato, Film Tilik

\section{INTRODUCTION}

The intention of the speaker can be captured properly by the speaker, and then some things must be considered. Speakers must understand the meaning of a speech as a whole, not only in terms of literal semantics but also in speakers' meaning from the pragmatic side. According to Yule (1996.) Pragmatic is the study of the relationship between linguistic forms and the users of that form. This means the relationship of an utterance to know the form and find out the purpose of the utterance. Pragmatic also finds out the meaning, purpose or purpose, and type of speech act of people. 
Speaking as a basic unit of language is an effective center of communication because they enable people to perform various functions such as asserting, asserting, blaming, inferring, explaining, informing, informing, praising, and much more (Yule, 1996). Speech acts are actions carried out through language. Through speech acts, people can do a single utterance with more than one action. People can make requests, orders, apologies, promises, and so on. Similar to Yule's (1970) definition defines speech acts as word sequences that behave like actions. By doing speech acts, speakers often try to achieve some effect with those words, effects that might have been achieved by alternative actions.

When a speaker produces an utterance, the speaker actually means something and at once acts the so-called Speech act. The acts could be making a statement, giving a command, asking a question, making a promise, and the like (Searle, 1970). That means speech acts as the basic unit of language and is central to effective communication because they allow people to do various functions. A speech act is a theory that analyzes the effect of an utterance in the relationship between the speaker and the listener's behavior. According to J. L. Austin, there are three types of speech acts, according to Austin (1962): locutionary acts, illocutionary acts, and perlocutionary acts. Locutionary act is the literal meaning of the utterances, the illocutionary act is the action behind the utterances, and perlocutionary act is the effect of utterances to the listener.

Speech act is found in a real-life situation and the magazine, newspaper, books, movie, etc. The movie is that the speaker uses one easy way to deliver the utterances. Monaco (2000) describes that movie is the sequence of pictures projected on a screen from a developer and prepared movie, especially with an accompanying soundtrack. Mostly, a movie is an artwork that reflects a human's real life. A movie is a form of artificial situation that emerges inspired by the social life developed in his time. The movie gives much picture about real-world reflection. This makes the movie interesting to be studied more deeply. The movie is literary discourse and including expressive discourse group.

Tilik movie is a viral movie in 2020. This movie is quite interesting and closely related to the real-life situation in our society. This movie is produced by Ravacana Films, which collaboration with the Culture Department of DIY in 2018 and has been watched 24 million viewers (Ravacana Films, 2020). This movie won some awards, such as Piala Maya (Short Movie Choice, Official Selection Jogja, 2018), Netpac Asian Film Festival, 2018 and Official Selection World Cinema, Amsterd, 2019. Besides it, the researcher assumes that are many speech acts found in this movie. Hence, it is related to be analyzed in this research. The researcher aims to identify and analyze speech acts, especially Illocutionary acts in Bu Tejo's Utterances in the Tilik Movie.

According to Searle (1996), the unit of linguistic communication is not, as is generally suspected, symbol, word or sentence, or even the sign of the symbol, word or sentences, but rather the production or publication of symbols or words or sentences in a speech act performance ". Searle's opinion can be interpreted that communication is more than just a symbol, word, or sentence. However, it would be more appropriate if the communication was called a product or the result of symbols, words, or sentences in the form of speech act behavior (the speech act performance). In other words, speech acts are a product or the result of a sentence under certain conditions and are the smallest unit of linguistic communication that can be statements, questions, orders, or others.

Speech has an important role in human life. People who want to become organizational leaders can transfer knowledge or share information if there is no way to write. Not only want to be leaders of organizations but also everyone who wants to 
provide important information (Purwadi Dede, 2009). A speaker communicates in spoken or face-to-face language and ins written language, such as in newspapers, magazines, books, novels, film scripts, short stories, and others (Khoirul, 2016). The speaker can convey sayings in the film to the public. A movie consists of an image project on a screen with a soundtrack.

One of the famous media in the world is movies. We can see the interesting side from movie. There are action, visual, location, situation, technology, and many more. Motion picture is the combination of movement, words, music, and colors (Aoudah, 2016). Movie itself has the kinds of genre. There are action, adventure, comedy, horror, musical, natural, drama, fantasy, etc. People often use regional languages in communicating, which is regional, for example, using Javanese, Sundanese, Madura, Bali, and others. This phenomenon takes place in a society open because members of the public can allow arrival members of other communities, either one or more of one society, and a language contact relationship. The language in society that allows will impact the language of the people who comes. In general, two or more languages play a role in the process of communicating

The Tilik Movie is short, has a drama genre, and all actors use Javanese. Tilik stories about Dian is a village flower. Many men approached her and came to propose to her. The Villagers talk about Dian's single status. On one occasion, on a trip by truck to visit (tilik) the Head of Urban Village at the hospital in the city, several residents argued about who would marry Dian. The "tilik" trip became full of talking and adventure for the villagers who boarded the truck.

There are several studies related to speech acts used by actors in a film. Some are focused on speech acts used by the main character or dialogue used by all actors. Surahman (2015) in his thesis, An Analysis Of Speech Acts In "Pirates Of The Caribbean: On Stranger Tides" Movie By Rob Marshall, he researched all types of speech act and That study was aimed to know the speech acts a form of the utterance among the character in Pirates of The Caribbean: On Stranger Tides movie script by Robb Marshall. The research described several findings on it. First, in the movie that he researched, the utterance can be analyzed in the speech act. Second, some utterances are found as representatives, directives, commissives, expressives, and declaratives. While (Zulfa Tutuarima, 2019) researched speech act on their researcher, An Analysis Of Speech Act Used In London Has Fallen Movie. This study's objectives were (i) to determine the types of speech acts used in the film London Has Fallen Movie (ii) to determine the manner of speech acts and the classification of illocutionary acts used in the London Has Fallen Movie. The results showed that: (i) There are 76 utterances used in the film London Has Fallen Movie, the most dominant is illocutionary, which consists of 37 utterances. (ii) The illocutionary classification expression consists of 99 expressions, and the most dominant category is a directive expression with 32 expressions and expressive with 23 expressions.

Most previous studies focus on the kind of speech act found in the dialogue or particular and used by all characters in a movie. In this research, the researcher is interested in finding the illocutionary acts used by the main character, $\mathrm{Bu}$ Tejo. In this study, the authors choose the "Tilik" movie by Ravacana Film because the illocutionary acts contained in the dialogue of this movie are very diverse. The research question is what kind of illocutionary acts and how many are used by Bu Tejo as main character in Tilik Movie

\section{RESEARCH METHODOLOGY}

The method of this research is qualitative research. According to Fraenkel and Norman (2009), qualitative research investigates the quality of relationships, activities, 
situations, or materials. Gerring (2007) This study is descriptive qualitative research with a natural setting as the direct source of data with the researcher taking the role of being the key instrument. Meanwhile, Nunan (1992) said, the descriptive study can investigate a person's description, an event, a group, or an institution.

In the data collection process, there were some of the following steps: 1 . The researchers downloaded the film script. 2. Second, the researcher watched the film more than once. 3. Third, the researcher reads and observed the dialogue from the script. 4. Fourth, researchers collected data by watching films. 5. Finally, researchers collected data to be grouped into categories of illocutionary act. The researchers took the sample data from Bu Tejo's utterances at the Tilik movie uploaded by Ravacava Films on Youtube on $17^{\text {th }}$ of August, 2020.

\section{FINDINGS AND DISCUSSION}

Searle (1997, in Levinson, 1983) classified illocutionary speech act into five types: assertive, directives, commissive, expressive, and declarative.

a. Assertives: in this illocution is bound to the truth the prepositions expressed, for example, state, propose, boast, complain, express opinions, report.

b. Directives: This illocution aims to produce an effect in the form of actions performed by speakers. This illocution, for example, orders, command, beg, demand, give advice.

c. Commissive: in this illocution are (more or less) bound on a future action, for example, promising, offering, vowed

d. Expressive: the function of this illocution is to express or expresses the speaker's psychological attitude to the situation that is implied in illocution, for example, saying thanks, saying congratulations, apologize, criticize, praise, and offer condolences.

e. Declarations: the success of this illocution will result in a match between the content of the proposition and reality, for example, resigning, baptizing, dismissing, giving a name, impose punishment, exclude/throw away, lift (employees).

According to Wijana (2009), types of speech acts can be divided into two types, namely direct speech acts and indirect speech acts. Direct speech acts are speech acts that have the harmony of sentence structure forms and communication functions. In contrast, indirect speech acts are speech acts that do not have harmony between the sentence structure and its communication function.

As a result of this research, 70 illocutionary acts were found in Bu Tejo's utterances, consisting of 41 representatives, 18 directives, and 11 expressives. Then, it found five types of illocutionary acts used by the main character, $\mathrm{Bu}$ Tejo, in the TILIK movie. There are:

1. Assertive

The assertive types are informing, describing, stating explaining, affirming, complaining, predicting, arguing, agreeing, and convincing.

2. Directive

The types of directive are warning, questioning, suggesting, commanding, requesting.

3. Expressive

The types of Expressive are expressing anger, expressing dislike, expressing possibility, mocking and panicking.

The illocutionary acts used by Bu Tejo are presented on the table below: 
Table 1. Illocutionary Acts

\begin{tabular}{clll}
\hline No & $\begin{array}{l}\text { Classification } \\
\text { acts }\end{array}$ & Illocutionary & \multicolumn{2}{c}{ Kinds of Illocutionary } \\
\hline 1 & Assertives (41) & 1.Informing (3) & 6. Agreeing (3) \\
& & 2.Stating (4) & 7. Predicting (6) \\
& & 3.Describing (2) & 8. Arguing (11) \\
& & 4. Affirming (4) & 9.Complaining (5) \\
& & 5.Explaning (4) & 10. Convincing (4) \\
\hline 2 & Directives (18) & 1.Warning (2) & 4.Suggesting (7) \\
& & 2.Questioning (4) & 5. Requesting (2) \\
\hline 3 & Expressive (11) & 3.Commanding (6) & \\
& & 1.Expressing of Dislike (3) \\
& & 2. Expressing of Possibility (3) \\
& & 3.Expresing of Anger (1) \\
& & 4. Mocking (2) & \\
& & 5.Panicking (1) & \\
\hline
\end{tabular}

Every finding illocutionary action is discussed in the following analysis.

1. Assertive

Bu Tejo: aku kebeleut nguyuh kih

This conversation occurred when bu Tejo said to the other that she wants to take to the bathroom.

2. Directive

$\mathrm{Bu}$ Tejo: pak polisi kami tuh mau tilik bu lurah. Ini keadaanya darurat, mbo tolong pak (excuse me Mr, we are going to visit Bu Lurah. Its emergency mr, please let us go!)

$\mathrm{Bu}$ Tejo: Mulane Yu ning sergepe moco berita soko internet (its time for you to upgrade your skill through the internet).

This conversation occurred when Yu Ning as an interlocutor of $\mathrm{Bu}$ Tejo and her friends, said about the bad story of Dian.

3. Expressive

Bu Tejo: Aku paling sengint mun ana kang kandani bapan bocahku (I hate if anyone talks about the father children)

This conversation occurred when Yu Ning as an interlocutor of Bu Tejo said that $\mathrm{Bu}$ Tejo's husband got the money illegally.

There are some similarities and differences between this research and the other research. The similarities in this research with Surahman's research (2015) are finding the illocutionary acts used in the movie's main character. Furthermore, the differences are the total, and the kinds of Illocutionary acts are found. The total illocutionary acts in this research is 70 . There were 3 types of illocutionary speech acts found in this research, and there are 41 types of assertive, 18 types of expressive, and the last 11 types of directive. Every type is classified into some kinds itself. Assertives were divided to 3 informing, 2 describing, 4 stating, 4 explaining, 4 affirming, 5 complaining, predicting, 11 arguing, 3 agreeing, 4 convincing. Directive divided into some kind there are 2 warning, 44 questioning, 7 suggesting, 6 commanding, 2 requesting. And the last is of expressive, there are 1 expressing anger, expressing 3 dislike, 3 expressing possibility, 2 mocking, and 1 panicking.

There are lots of conversations that contain predictions and also many arguments. Some conversations can lead people to think about the character being talked about because, in this case, many things are not true in the conversations. 


\section{CONCLUSION}

Based on the result and finding that the illocutionary acts that used by Bu Tejo in Tilik Movie that 3 types are found in this Movie. 1) Assertive. 2) declarative. 3) Expressive. The assertive types are informing, describing, stating explaining, affirming, complaining, predicting, arguing, agreeing, and convincing. Meanwhile, the types of declarative are warning, questioning, suggesting, commanding, requesting. And the types of expressive are expressing anger, expressing dislike, expressing possibility, mocking, and panicking. The study concludes that the speech act in this film script is to establish that something associated to a sealed grouping to express that someone is out of control, to show or express friendliness, to lessen badness discussion to persuade someone in a conversation.

\section{REFERENCES}

Austin, J. L. (1962). How to Do Things with World. Oxford University Press.

Fraenkel, J. R., \& Norman, E. (2009). How to Design and Evaluate Research in Education. McGraw-Hill.

Gerring, J. (n.d.). Case Study Research: Principles and Practices ((2007)). Cambridge University Press.

Aoudah, H. (2016). A Study of Social Values in The Legend of Korra; A Film Directed By Michael Dante Dimartino And Bryan Konietzko,. University of Mataram, 4.

Levinson, S. (1983). Pragmatics. Cambridge University Press.

Monaco, J. (2000). How To Read a Film. Oxford University Press.

Nunan, D. (1992). Research Method in Language Learning. Cambridge University Press.

Purwadi, D. (2009). Speech acts in Julia Gillard's Speeches. Masaryk University In Brno Faculty of Education Department of English Language And Literature.Brno, 12.

Ravacana Films. (2020). Tilik. https://www.youtube.com/watch?v=GAyvgz8_zV8\&t=1721s

Searle, J. (1970). What is Speech acth. Cambridge University Press, 7.

Surahman. (2015). An Analysis Of Speech Acts In "Pirates Of The Caribbean: On Stranger Tides" Movie By Rob Marshall. IAIN Syekh Nurjati.

Tutuarima, Z. (2019). An Analysis of Speech Act Used in London Has Fallen Movie. Adress Vision Journal for Language and Foreign Language Learning, 140.

Wijana I. D. P. (2009). Analisis Wacana Pragmatik: Kajian teori dan analisis. Yuma Pustaka.

Yule, G. (1996). Pragmatics. Oxford: OUP.

Zamzami, M. K.. (2016). Speech Act Used by Elsa as One of The Main Characters in Frozen Movie Script. IAIN Tulung Agung. 